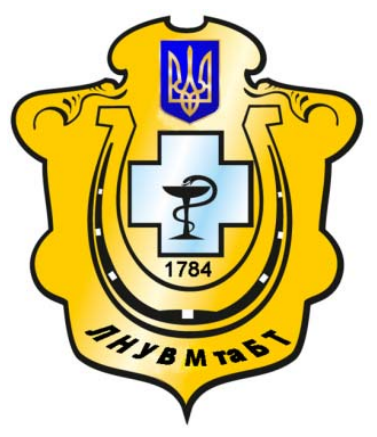

Науковий вісник Львівського національного університету ветеринарної медицини та біотехнологій імені С.3. Гжицького

Scientific Messenger of Lviv National University of Veterinary Medicine and Biotechnologies named after S.Z. Gzhytskyj

doi:10.15421/nvlvet6803

ISSN 2413-5550 print

ISSN $2518-1327$ online

$\underline{\text { http://nvlvet.com.ua/ }}$

УДК 621.311.61

\title{
Математичне моделювання процесів в електроприводі водяного насоса 3 акумуляторними батареями
}

\author{
Г.Й. Боднар 1, О.В. Шаповалов ${ }^{1}$, Я.І. Федишин ${ }^{2}$, Т.В. Гембара ${ }^{1}$ \\ taras.gembara@gmail.com
}

Львівський державний університет безпеки життєдіяльності,

вул. Клепарівська, 35, м. Львів, 79000, України;

Львівський наџіональний університет ветеринарної медицини та біотехнологій імені С.З. Гжиџького,

вул. Пекарська, 50, м. Львів, 79010, Україна

\begin{abstract}
Розглядається схема електроживлення електроприводу водяного насоса підвищувача тиску води системи внутрішнього протипожежного водопроводу від резервного джерела з акумуляторними батареями $і$ автономними інверторами напруги, ї̈ математична модель та результати моделювання електромагнітних і електромеханічних процесів в двигуні під час пуску і роботи насоса у випадку відсутності основного електроживлення від мережі, шчо забезпечує використання внутрішнього протипожежного водопроводу при надзвичайних ситуачіях протягом розрахункового часу. Така резервна система може використовуватись також для підтримки неперервності технологічних процесів.

Загальна математична модель електроприводу формувалась з математичних моделей окремих елементів схеми, які представлені багатополюсниками, а проиеси в них описуються замкненою системою рівнянь, - диференційних, алгебрайчних та логічних. Розрахункову схему моделі електроприводу сформовано иляхом з'єднання між собою зовнішніх віток окремих елементів-багатополюсників, а саме: джерела живлення з акумуляторною батареєю, інверторів напруги(катодні та анодні вентильні групи), трансформаторів та асинхронного двигуна. Спосіб з'єднання між собою зовнішніх віток багатополюсників математично описується матрицями з'єднань, які складаються для кожного елемента за принципом: кількість рядків матрииі рівна кількості незалежних вузлів схеми, а кількість стовпиів рівна кількості зовнішніх віток елемента. Обчислення реалізовано мовою FORTRAN. Загальні підпрограми призначені для виконання математичних операиій над матрииями; чисельного інтегрування систем диферениійних рівнянь методом Рунге-Кутта 2-го порядку; розв'язування систем алгебрайчних рівнянь методом Гауса; визначення моментів природного закривання вентилів. Отримано результати моделювання при прямому пуску асинхронного двигуна від мережі, встановлено струм статора; кутову швидкість обертання ротора та електромагнітний момент і момент навантаження. Результати обчислень підтверджені даними експериментальних досліджень, практично співпадають криві струму і напруги живлення асинхронного двигуна від мережі і автономного джерела з акумуляторною батареєю при пуску і роботі насоса, форма вихідної напруги джерела і тиску насоса, впродовж тривалої роботи електроприводу насоса.
\end{abstract}

Ключові слова: автономне електрожсилення, асинхронний двигун, математична модель,електромагнітні та електромеханічні процеси, акумуляторні батареї, водяний насос, технологічні процеси.

\section{Математическое моделирование процессов в электроприводе водяного насоса с аккумуляторными батареями}

\author{
Г.Й. Боднар, О.В. Шаповалов ${ }^{1}$, Я.И. Федишин ${ }^{2}$, Т.В. Гембара ${ }^{1}$ \\ taras.gembara@gmail.com \\ ${ }^{1}$ Львовский государственный университет безопасности жизнедеятельности, \\ ул. Клепаровская, 35, г. Львов, 79000, Украина; \\ ${ }^{2}$ Львовский национальный университет ветеринарной медицины и биотехнологий имени С.З. Гжицкого,
}

Citation:

Bodnar, G.J., Shapovalov, O.V., Fedyshyn, J.I., Hembara, T.V. (2016). Mathematical modeling of processes in the electric drive of water pump with batteries. Scientific Messenger LNUVMBT named after S.Z. Gzhytskyj, 18, 2(68), 11-20. 


\title{
ул. Пекарская, 50, г. Львов, 79010, Украина
}

Рассматривается схема электропитания электропривода водяного насоса повышателя давления воды системы внутреннего противопожарного водопровода от резервного источника с аккумуляторными батареями и автономными инверторами напряжения, ее математическая модель и результаты моделирования электромагнитных и электромеханических прочессов в двигателе при пуске и работе насоса в случае отсутствия основного электропитания от сети, что обеспечивает использование внутреннего противопожарного водопровода при чрезвычайных ситуаииях в течение расчетного времени. Такая резервная система может использоваться также для поддержки непрерывности технологических процессов.

Общая математическая модель электропривода формировалась из математических моделей отдельных элементов схемы, которые представлены многополюсниками, а прочессы в них описываются замкнутой системой уравнений, - дифференциальных, алгебраических и логических. Расчетную схему модели электропривода сформировано путем соединения между собой внешних веток отдельных элементов-многополюсника, а именно: источники питания с аккумуляторной батареей, инверторов напряжения (катодные и анодные вентильные группы), трансформаторов и асинхронного двигателя. Способ соединения между собой внешних веток многополюсника математически описывается матрицами соединений, состояших для каждого элемента по приниип: количество строк матрицы равно количеству независимых узлов схемы, а количество столбиов равно количеству внешних веток элемента. Вычисления реализовано на языке FORTRAN. Oбщие подпрограммы предназначены для выполнения математических операций над матрицами; численного интегрирования систем дифференциальных уравнений методом Рунге-Кутта 2-го порядка; решения систем алгебраических уравнений методом Гаусса; определения моментов природного закрытия вентилей. Получены результаты моделирования при прямом пуске асинхронного двигателя от сети, установлено ток статора; угловую скорость вращения ротора и электромагнитный момент и момент нагрузки. Результаты вычислений подтверждены данными экспериментальных исследований, практически совпадают кривые тока и напряжения питания асинхронного двигателя от сети и автономного источника с аккумуляторной батареей при пуске и работе насоса, форма выходного напряжения источника и давления насоса в течение длительной работы электропривода насоса.

Ключевые слова: автономное электропитание, асинхронный двигатель, математическая модель, электромагнитные и электромеханические процессы, аккумуляторные батареи, водяной насос, технологические процессы.

\section{Mathematical modeling of processes in the electric drive of water pump with batteries}

\author{
G.J. Bodnar, O.V. Shapovalov', J.I. Fedyshyn ${ }^{2}$, T.V. Hembara ${ }^{1}$ \\ taras.gembara@gmail.com \\ Lviv State University of Life Safety, \\ Kleparivska Str.,35, Lviv, 79000, Ukraine; \\ Lviv National University of Veterinary Medicine and Biotechnologies named after S.Z. Gzhytskyj, \\ Pekarska Str., 50, Lviv, 79010, Ukraine
}

We consider scheme of power supplies of the water pump's electric drive of increase of water pressure of system of internal fire water supply from the backup source with batteries and autonomous voltage inverter, its mathematical model and simulation results of electromagnetic and of electromechanical processes in the engine during start-up and operation of the pump in absence of the main power on the network, that provides use internal fire water supply at extraordinary situations during the estimated time. This reserve system can also be used to support the continuity of processes.

General mathematical model of electric drive formed with mathematical models of individual elements of the scheme represented of multipoles, and the processes in them describe a closed system of equations - differential, algebraic and logical. The estimated model of electric drive formed by the connection between the external branches of individual elements-multipoles, namely the power supply with the battery, inverter voltage (cathode and anode of valve group), transformers and induction motor. The way connection between the external branches of individual elements-multipoles mathematically described of matrices connections that draw up for each item on the principle: the number of rows equal number of independent units of the scheme and the number of columns equal to the number of external branches of element. Calculating implemented by language of FORTRAN. Common routines designed to perform mathematical operations on matrices; numerical integration of differential equations by the Runge-Kutta 2nd order; solution systems of algebraic equations by Gauss; definition moment of natural closing valves. The results of modeling the direct start induction motor from the network, the stator current; rotor's angular velocity and electromagnetic torque and moment loads was set. The calculation results confirmed those of experimental studies, almost identical curves of current and voltage induction motor from the network and independent source of battery at start-up and operation of the pump, the shape of the output voltage source and a pressure of pump during continuous operation of the electric pump.

Key words: autonomous power supplies, induction motor, mathematical model, electromagnetic and electromechanical processes, rechargeable battery, water pump, technological processes.

\section{Вступ}

У відповідності до вимог Правил пожежної безпеки України та інших нормативних документів визначено перелік будівель та споруд, обладнаних внутрішніми протипожежними водопроводами (ВПВ), в яких для забезпечення необхідного тиску води використовують відцентрові насоси 3 нерегульованим електроприводом на базі асинхронних двигунів 3 короткозамкнутим ротором (АД). Живлення цих двигунів здійснюють від трифазної мережі змінного струму. Згідно Правил улаштування електроустано- 
вок в системах протипожежного захисту мають бути резервні джерела електроживлення. Тому в усіх системах протипожежного захисту використовують другий ввід живлення від підстанції і автономні генераторні установки $з$ двигунами внутрішнього згорання.

В умовах надзвичайних ситуацій природного чи техногенного характеру при пожежах електричні мережі знеструмлюються, що не дає змогу використовувати системи протипожежного захисту в таких умовах. Тому постає необхідність розробки та дослідження схем електроживлення систем протипожежного захисту від альтернативних автономних джерел енергії.

Основними параметрами, що характеризують ефективність функціонування системи протипожежного водопостачання $є$ напір (тиск) та витрата вогнегасної речовини, які забезпечує водяний насос. Для приводу насосів використовують надійні та прості в експлуатації АД, об’єктом обслуговування в яких є лише підшипники. Основними джерелами електричної енергії $\epsilon$ електромережі загального використання 3 подвійними вводами від підстанцій та додаткове резервування за допомогою електрогенеруючих установок 3 двигунами внутрішнього згорання, які являють собою небезпеку, пов'язану з використанням горючих та легкозаймистих речовин. Вимоги до забезпечення електроживлення електроприводу водяних насосів систем протипожежного водопостачання не змінювались 3 70-х років.

Незважаючи на значний прорив в розробці і виготовленні двигунів, які використовуються в генераторних установках, для забезпечення їх стабільної роботи все більше звертають увагу на електронні пристрої, що управляють роботою і значно зменшують час на приведення їх в дію. Встановлений в приміщенні генератор 3 часом нагрівається, нагріті його частини можуть бути джерелами займання. Поєднання цих чинників може бути причиною виникнення пожежі. Відомі факти, коли саме генераторні установки були причиною надзвичайних ситуацій. Окрім цього такі установки спричиняють шуми.

У роботі (Shesterenko, 2004), на основі тривалих досліджень елементів систем електропостачання підприємств харчових технологій, проведено грунтовний аналіз проектування та оптимізації цих систем. Значна увага надається забезпеченню автономного резервного електропостачання, що важливо з точки зору гарантування неперервності технологічного процесу. В даному випадку його можна отримати 3 альтернативного автономного джерела електроенергії з акумуляторними батареями і інверторами напруги, притому накопичення енергії може здійснюватись від джерела мережі, або інших, екологічних джерел, наприклад вітроенергетичних, сонячних елементів та ін. Зауважимо, що такі розробки придатні і для універсального застосування, як для систем протипожежного захисту, так і систем забезпечення неперервності технологічних процесів у надзвичайних ситуаціях. Метою даної роботи є розробка схеми електроприводу насоса підвищувача тиску води системи протипо- жежного водопостачання, що живиться від альтернативного автономного джерела електроенергії з акумуляторними батареями i інверторами напруги, іiі математичної моделі для дослідження електромагнітних та електромеханічних процесів в АД під час пуску і роботи насоса.

\section{Матеріал і методи досліджень}

Математичне моделювання електромашиновентильних систем, чисельні методи розв'язування систем диференціальних рівнянь.

\section{Результати та їх обговорення}

Відомим і широко використовуваним принципом відбору і перетворення енергії $\epsilon$ резервування електричної енергії в акумуляторних батареях (АБ). Сучасна промисловість випускає великий спектр АБ різного призначення, які відрізняються параметрами,- величиною напруги, ємністю, розмірами, вагою. До переваг АБ можна віднести здатність зберігати певний заряд енергії упродовж тривалого часу. Відсутність в АБ інерційності зменшує час пуску в роботу будьякої системи до мінімального.

На основі порівняння основних характеристик АБ, до яких відносяться енергетична щільність електроенергії, внутрішній опір, саморозряд, число циклів заряд-розряд, струм навантаження і діапазон робочих температур, кращі за характеристиками для застосування в якості резервного живлення можуть бути літій-іонні, літій-полімерні і кислотні АБ.

Застосування в якості резервного джерела електроживлення для пристроїв, установок та систем захисту АБ в комплексі з автономними інверторами напруги(АIH), які випускаються у вигляді окремих модулів (Seki et al., 1995; Brunner et al., 1995), дасть змогу зменшити незалежність систем протипожежного захисту від загальних електричних мереж. Тому для резервування електроживлення електроприводу водяного насоса ВПВ запропонована схема з АБ і АІН, рис. 1 (Bodnar and Shapovalov, 2014).

На схемі позначено: блок АБ (АБ1, АБ2, АБ3); блок тиристорів підключення (VS1,VS2,VS3); AIH1, AIH2 - трифазні автономні інвертори напруги; ТT трифазні трансформатори; АД - привідний асинхронний двигун; Н - насос; система керування. У схемі AIH1, АIH2 по вхідному колу з'єднані паралельно, а вихідними - через елементи додавання - трифазні трансформатори ТТ під'єднанні до АД. Внаслідок того, що між моментами включення вентилів AIH1 i AIH2 у часі є зміщення, з одного боку, і зміщення, яке забезпечується між фазними напругами схемами з'єднань обмоток трансформаторів ТТ, 3 другого боку, в схемі компенсуються вищі гармоніки, які є в складі напруг на виході AIH (Plahtyna et al., 1998; Bodnar and Shapovalov, 2012). Тому напруга живлення АД має квазісинусоїдну форму. Коефіцієнт гармонік становить $12 \%$. 


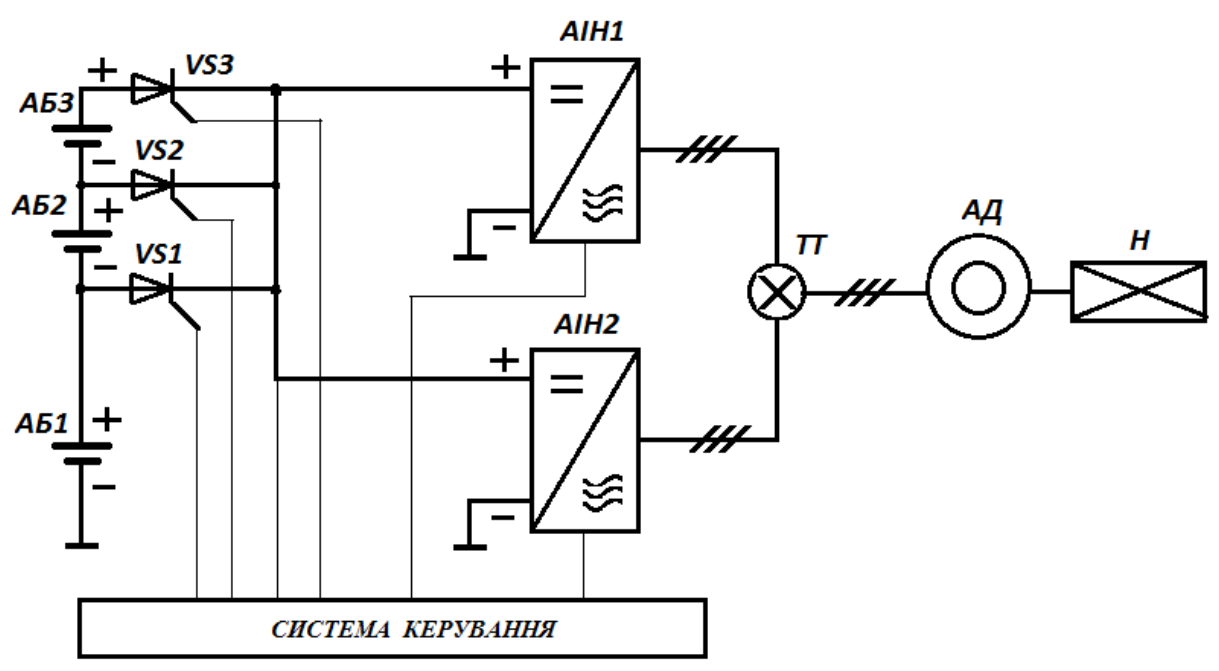

Рис.1. Блок-схема електроприводу

Для зменшення втрат енергії під час пуску насоса у схемі передбачено ступінчасте керування процесом пуску АД за законом частотного регулювання, рис. 2 (Bodnar and Shapovalov, 2008). Під'єднання АБ до AIH здійснюють тиристори VS1,VS2,VS3 (рис.1).

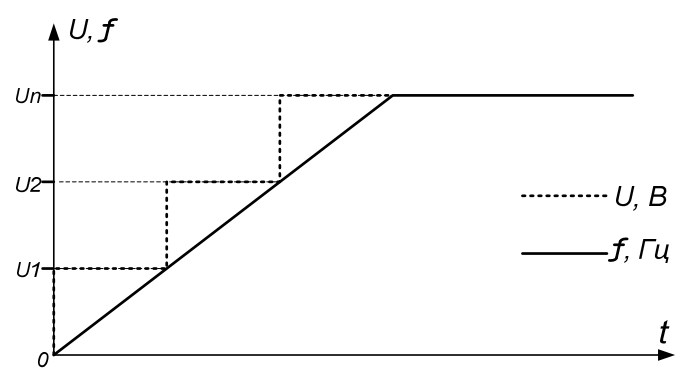

Рис.2. Закон керування пуском АД

Закон зміни напруги живлення АД під час пуску насоса має вигляд:

$$
\frac{U_{1}}{f_{1}}=\frac{U_{2}}{f_{2}}=\frac{U_{3}}{f_{3}}=\text { const },
$$

де $U, f$ - відповідно напруга і частота живлення АД.

$$
u=u(t)=\left\{\begin{array}{cc}
\mathrm{U}_{1}=\Delta \mathrm{U}_{1}=\mathrm{E}_{1}, & 0 \leq \mathrm{f}<\mathrm{f}_{1} \\
\mathrm{U}_{2}=\mathrm{U}_{1}+\Delta \mathrm{U}_{2}=\mathrm{E}_{1}+\mathrm{E}_{2}, & \mathrm{f}_{1} \leq \mathrm{f}<\mathrm{f}_{2} \\
\mathrm{U}_{3}=\mathrm{U}_{2}+\Delta \mathrm{U}_{3}=\mathrm{E}_{1}+\mathrm{E}_{2}+\mathrm{E}_{3}, & \mathrm{f}_{2} \leq \mathrm{f}<\mathrm{f}_{3}
\end{array}\right.
$$

де $E_{1}, E_{2}, E_{3}$-e.p.c. відповідно АБ1, АБ2,АБ3.

На основі теорії математичного моделювання електромашино-вентильних систем (Plahtyna, 1986) для дослідження процесів в АД створено математичну модель електроприводу. Згідно цієї теорії математична модель електроприводу насоса формувалась 3 математичних моделей окремих елементів, серед яких: АБ,VS1,VS2,VS3, АІН1, АІН2, ТТ, АД, Н, система керування. Усі перелічені елементи в моделі представлені багатополюсниками, процеси в яких описуються замкненою системою рівнянь (диференційних, алгебраїчних, логічних). Кожний елемент представлено зовнішнім векторним рівнянням виду

$$
\mathrm{p} \overrightarrow{\mathrm{i}}_{\mathrm{e}}+\breve{\mathrm{G}}_{\mathrm{e}} \cdot \vec{\varphi}_{\mathrm{e}}+\overrightarrow{\mathrm{C}}_{\mathrm{e}}=0
$$

де $-\overrightarrow{\mathrm{i}}_{\mathrm{e}}=\left(\mathrm{i}_{1}, \ldots, \mathrm{i}_{\mathrm{n}}\right)_{\mathrm{t}} ; \vec{\varphi}_{\mathrm{e}}=\left(\vec{\varphi}_{1}, \ldots, \vec{\varphi}_{\mathrm{n}}\right)_{\mathrm{t}}-$ вектори струмів зовнішніх віток та потенціалів зовнішніх полюсів багатополюсника; $\breve{\mathrm{G}}_{\mathrm{e}}, \overrightarrow{\mathrm{C}}_{\mathrm{e}}$ - відповідно матриця $(\mathrm{n} \times \mathrm{n})$ і вектор розмірністю $\mathrm{n}$, які визначаються параметрами структурного елемента; $\mathrm{n}$ - кількість полюсів електричного багатополюсника. Векторне рівняння виду (2) отримується шляхом застосування законів електротехніки для електричних кіл 3 подальшими алгебраїчними перетвореннями.

Крім векторного рівняння виду (2) електричний багатополюсник описується ще й внутрішніми рівняннями, які використовуються для розрахунку змінних, що не відносяться до струмів зовнішніх віток.

Розрахункову схему моделі електроприводу (рис. 3) сформовано шляхом з'єднання між собою зовнішніх віток елементів-багатополюсників. Спосіб з'єднання між собою зовнішніх віток багатополюсників математично описується матрицями з'єднань Пј, які складаються для кожного елемента за таким принципом: кількість рядків матриці рівна кількості незалежних вузлів схеми (точок 3'єднання між собою зовнішніх віток багатополюсників, причому, кількість незалежних вузлів для гальванічно-зв'язаної схеми на одиницю менша від загальної кількості вузлів), а кількість стовпців рівна кількості зовнішніх віток елемента. Елементами матриці є 0 i 1. Якщо i-та зовнішня вітка структурного елемента входить в $\mathrm{j}-$ ий незалежний вузол схеми то на перетині i-го стовпчика та j-го рядка записується 1 , всі інші елементи матриці рівні 0 .

Співвідношення між потенціалами зовнішніх полюсів елементів-багатополюсників та потенціалами незалежних вузлів схеми описується рівнянням (Bodnar and Shapovalov, 2010):

$$
\vec{\varphi}_{\mathrm{e}}=\breve{\Pi}_{\mathrm{j}}^{\mathrm{T}} \cdot \varphi_{\mathrm{c}},
$$


де $\vec{\varphi}_{\mathrm{c}}$ - вектор потенціалів незалежних вузлів схеми.

Потенціали незалежних вузлів ЕМВС можуть бути визначені $з$ векторного рівняння виду (Plahtyna, 1986):

$$
\breve{\mathrm{G}}_{\mathrm{c}} \cdot \vec{\varphi}_{\mathrm{c}}+\overrightarrow{\mathrm{C}}_{\mathrm{c}}=0
$$

де коефіцієнти визначаються на основі коефіцієнтів зовнішнього вузлового векторного рівняння виду (2) кожного структурного елемента та матриць з'єднань елемента за формулами (Plahtyna, 1986):

$$
\breve{\mathrm{G}}_{\mathrm{c}}=\sum_{\mathrm{j}=1}^{\mathrm{m}} \breve{\mathrm{\Pi}}_{\mathrm{j}} \cdot \breve{\mathrm{G}}_{\mathrm{ej}} \cdot \breve{\mathrm{\Pi}}_{\mathrm{j}}^{\mathrm{T}} ; \quad \overrightarrow{\mathrm{C}}_{\mathrm{c}}=\sum_{\mathrm{j}=1}^{\mathrm{m}} \breve{\Pi}_{\mathrm{j}} \cdot \overrightarrow{\mathrm{C}}_{\mathrm{ej}},
$$

де $\mathrm{m}$ - кількість елементів, що входять до складу EMBC

Рівняння (2), (3), (4) разом 3 внутрішніми рівняннями електричних багатополюсників формують математичну модель схеми електроприводу.

Під час математичного моделювання на кожному кроці чисельного інтегрування розраховують вектор інтегральних змінних $\vec{y}$, елементами якого $\epsilon$ всі змін- ні, які описують структурні елементи схеми, і інтегруються, тобто $\vec{y}=\vec{y}(t)$. Похідні інтегральних змінних входять до складу вектора інтегрування $p \vec{y}$, який формується з векторів інтегрування структурних елементів схеми, похідних змінних, що не входять у вектори інтегрування структурних елементів. У вектори інтегрування структурних елементів $\vec{p}_{\mathrm{e}}$ входять вектор похідних струмів зовнішніх віток $\mathrm{p} \overrightarrow{\mathrm{i}}_{\mathrm{e}}$, який визначається з рівняння (2) та похідні змінних внутрішніх рівнянь багатополюсника (можуть бути відсутні).

Відповідно до обраного підходу, математична модель електроприводу насоса ВПВ формувалася шляхом композиції математичних моделей окремих елементів-багатополюсників, а саме: джерела живлення (Дж) 3 АБ, інверторів напруги АIH1, AIH2 (катодні вентильні групи КВГ1 - КВГ4 та анодні вентильні групи АВГ1 - АВГ4), трансформаторів Тр1 - Тр2 та асинхронного двигуна АД. Розрахункова схема силової частини електроприводу насоса показана на рис. 3 .

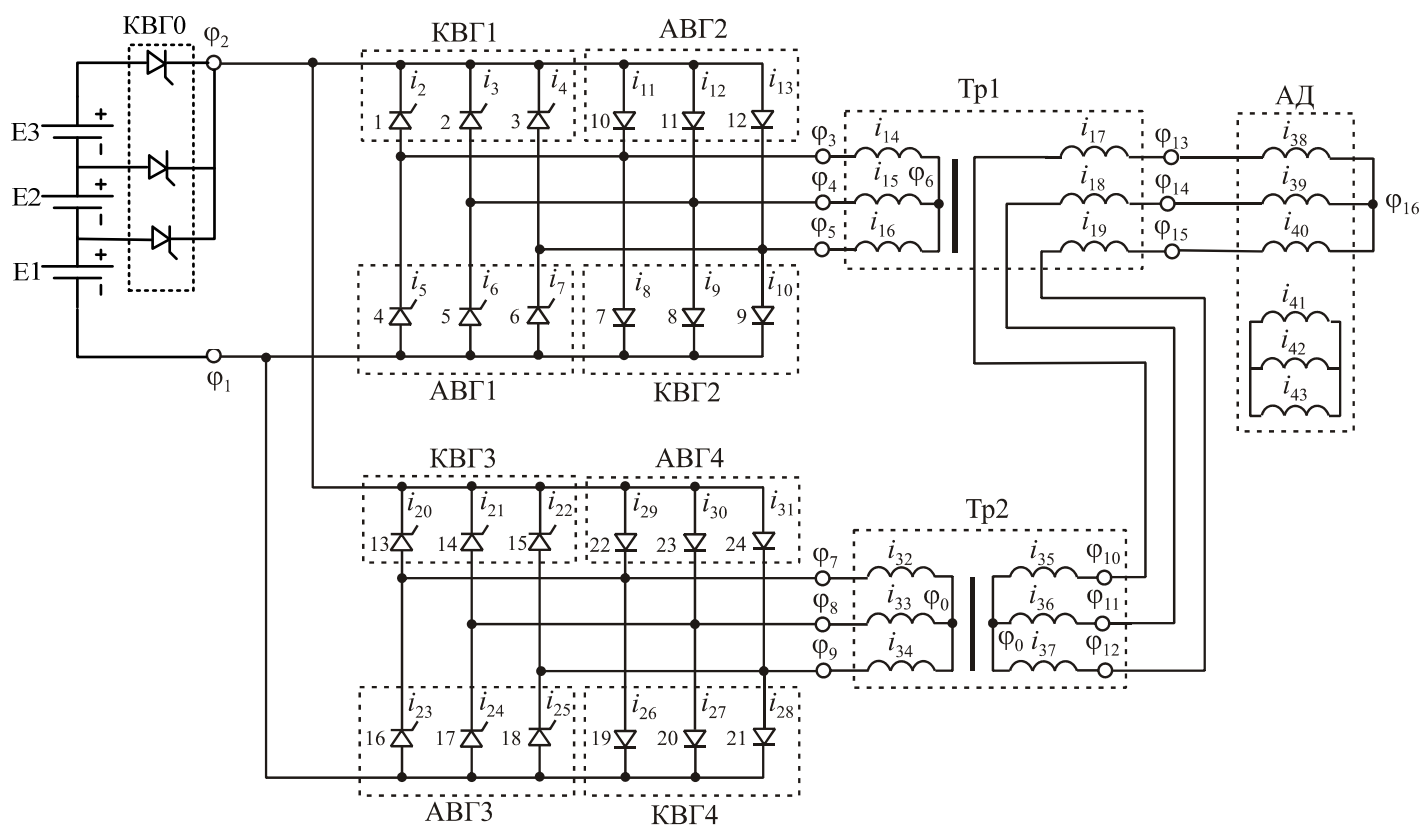

Рис. 3. Розрахункова схема електроприводу насоса

Згідно (Plahtyna, 1986), математична модель схеми формується 3 використанням математичних моделей структурних елементів, представлених зовнішніми вузловими векторними рівняннями елементів (2):

$$
\mathrm{p} \overrightarrow{\mathrm{i}}_{\mathrm{RL}}+\breve{\mathrm{G}}_{\mathrm{RL}} \vec{\varphi}_{\mathrm{RL}}+\overrightarrow{\mathrm{C}}_{\mathrm{RL}}=0-\text { джерела живлен- }
$$
ня. $\overrightarrow{\mathrm{i}}_{\mathrm{B}}+\breve{\mathrm{G}}_{\mathrm{B}} \vec{\varphi}_{\mathrm{B}}+\overrightarrow{\mathrm{C}}_{\mathrm{B}}=0,($ в $\rightarrow$ АВГ1, АВГ2, АВГ3, АВГ4, КВГ1, КВГ2, КВГЗ, КВГ4) - анодних та катодних вентильних груп АIH1 і AIH2.

$$
\mathrm{p} \overrightarrow{\mathrm{i}}_{\mathrm{T}}+\breve{\mathrm{G}}_{\mathrm{T}} \vec{\varphi}_{\mathrm{T}}+\overrightarrow{\mathrm{C}}_{\mathrm{T}}=0 \quad(\mathrm{~T} \rightarrow \mathrm{Tp} 1, \mathrm{Tp} 2)-\text { трифазних }
$$
трансформаторів.
$\mathrm{p}_{\mathrm{am}}+\breve{\mathrm{G}}_{\text {ам }} \vec{\varphi}_{\text {ам }}+\overrightarrow{\mathrm{C}}_{\text {ам }}=0$ - асинхронної машини, АД.

Дані рівняння та їх коефіцієнти описані в [7,9,10,].

Зовнішнє вузлове векторне рівняння системи(рис. 3) матиме вигляд:

$\breve{\mathrm{G}}_{\mathrm{c}} \cdot \vec{\varphi}_{\mathrm{c}}+\overrightarrow{\mathrm{C}}_{\mathrm{c}}=0$

де $\vec{\varphi}_{\mathrm{c}}=\left(\varphi_{1}, \varphi_{2}, \ldots, \varphi_{16}\right)_{\mathrm{t}}-$ вектор потенціалів незалежних вузлів системи.

Коефіцієнти зовнішнього вузлового векторного рівняння системи, зідно з (5), визначаються так 


$$
\begin{aligned}
& \breve{\mathrm{G}}_{\mathrm{c}}=\breve{\Pi}_{\text {Дж}} \cdot \breve{\mathrm{G}}_{\text {Дж}} \cdot \breve{\Pi}_{\text {Дж }}^{\mathrm{T}}+\breve{\Pi}_{\mathrm{AB} 1} \cdot \breve{\mathrm{G}}_{\mathrm{AB} \Gamma 1} \cdot \breve{\Pi}_{\mathrm{AB} \Gamma 1}^{\mathrm{T}}+\breve{\Pi}_{\mathrm{KB} \Gamma 1} \cdot \breve{\mathrm{G}}_{\mathrm{KB} \Gamma 1} \cdot \breve{\Pi}_{\mathrm{KB} \Gamma 1}^{\mathrm{T}}+
\end{aligned}
$$

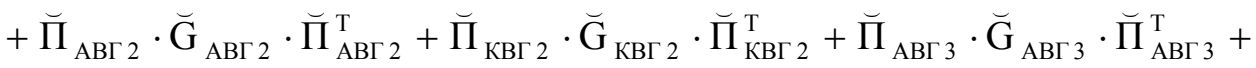

$$
\begin{aligned}
& +\breve{\Pi}_{\text {КВГ } 3} \cdot \breve{\mathrm{G}}_{\mathrm{KBГ} 3} \cdot \breve{\Pi}_{\mathrm{KB} Г 3}^{\mathrm{T}}+\breve{\Pi}_{\mathrm{AB \Gamma} 4} \cdot \breve{\mathrm{G}}_{\mathrm{AB \Gamma} 4} \cdot \breve{\Pi}_{\mathrm{AB \Gamma} 4}^{\mathrm{T}}+\breve{\Pi}_{\mathrm{KBГ} 4} \cdot \breve{\mathrm{G}}_{\mathrm{KBГ} 4} \cdot \breve{\Pi}_{\mathrm{KB} \text { 4 } 4}^{\mathrm{T}}+ \\
& +\breve{\Pi}_{\mathrm{Tp} 1} \cdot \breve{\mathrm{G}}_{\mathrm{Tp} 1} \cdot \breve{\Pi}_{\mathrm{Tp} 1}^{\mathrm{T}}+\breve{\Pi}_{\mathrm{Tp} 2} \cdot \breve{\mathrm{G}}_{\mathrm{Tp} 2} \cdot \breve{\Pi}_{\mathrm{Tp} 2}^{\mathrm{T}}+\breve{\Pi}_{\mathrm{am}} \cdot \breve{\mathrm{G}}_{\mathrm{am}} \cdot \breve{\Pi}_{\mathrm{am}}^{\mathrm{T}} \text {, } \\
& \breve{\mathrm{C}}_{\mathrm{c}}=\breve{\Pi}_{\text {Дж }} \cdot \breve{\mathrm{G}}_{\text {Дж }}+\breve{\Pi}_{\mathrm{AB} \Gamma 1} \cdot \breve{\mathrm{G}}_{\mathrm{AB} \Gamma 1}+\breve{\Pi}_{\mathrm{KB} \Gamma 1} \cdot \breve{\mathrm{G}}_{\mathrm{КВ} \Gamma 1}+\breve{\Pi}_{\mathrm{AB} Г 2} \cdot \breve{\mathrm{G}}_{\mathrm{AB} Г 2}+ \\
& \breve{\Pi}_{\text {КВГ2 } 2} \cdot \breve{\mathrm{G}}_{\mathrm{КВГ} 2}+\breve{\Pi}_{\mathrm{ABГ} 3} \cdot \breve{\mathrm{G}}_{\mathrm{ABГ} 3}+\breve{\Pi}_{\mathrm{KВГ} 3} \cdot \breve{\mathrm{G}}_{\mathrm{KВГ} 3}+\breve{\Pi}_{\mathrm{ABГ} 4} \cdot \breve{\mathrm{G}}_{\mathrm{ABГ} 4}+ \\
& \breve{\Pi}_{\mathrm{KB} Г} \cdot \breve{\mathrm{G}}_{\mathrm{KB} \Gamma 4}+\breve{\Pi}_{\mathrm{Tp} 1} \cdot \breve{\mathrm{G}}_{\mathrm{Tp} 1}+\breve{\Pi}_{\mathrm{Tp} 2} \cdot \breve{\mathrm{G}}_{\mathrm{Tp} 2}+\breve{\Pi}_{\mathrm{am}} \cdot \breve{\mathrm{G}}_{\mathrm{am}} \text {, }
\end{aligned}
$$

де $\breve{\mathrm{G}}_{\mathrm{j}}, \overrightarrow{\mathrm{C}}_{\mathrm{j}}, \breve{\Pi}_{\mathrm{j}}(\mathrm{j} \rightarrow$ Дж, АВГ1, АВГ2, АВГ3, АВГ4, КВГ1, КВГ2, КВГЗ, КВГ4, Тр1, Тр2, АМ) - коефіцієнти зовнішніх вузлових векторних рівнянь елементів схеми та матриці з’єднань цих елементів, які рівні:

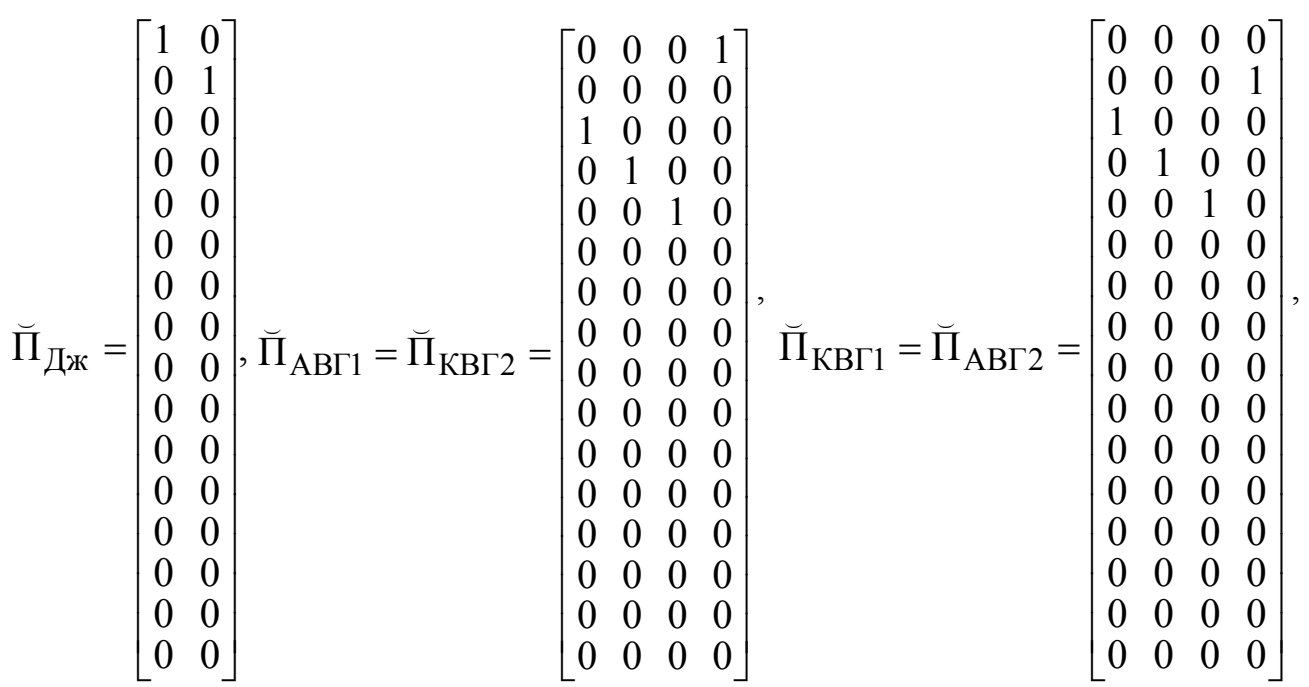

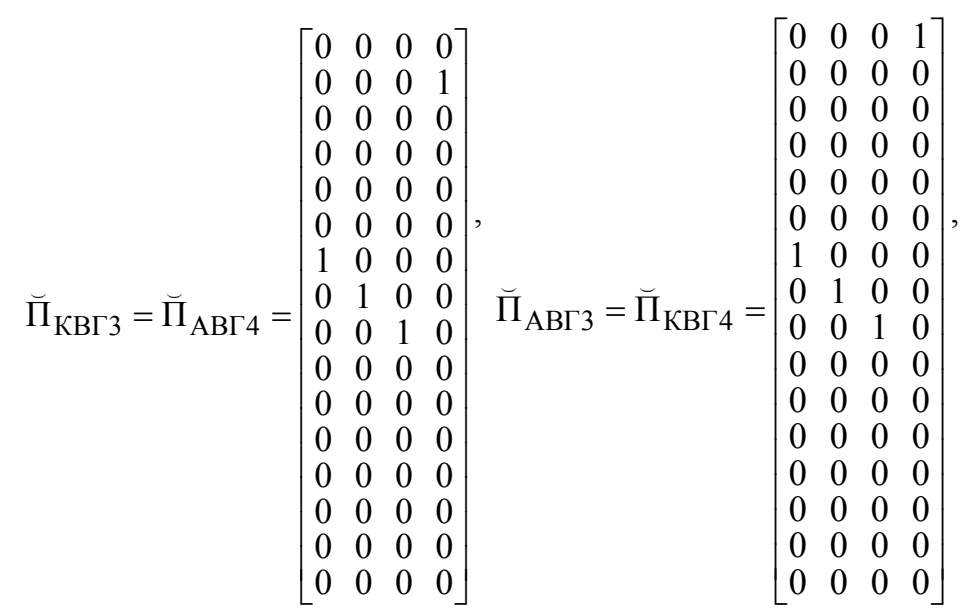




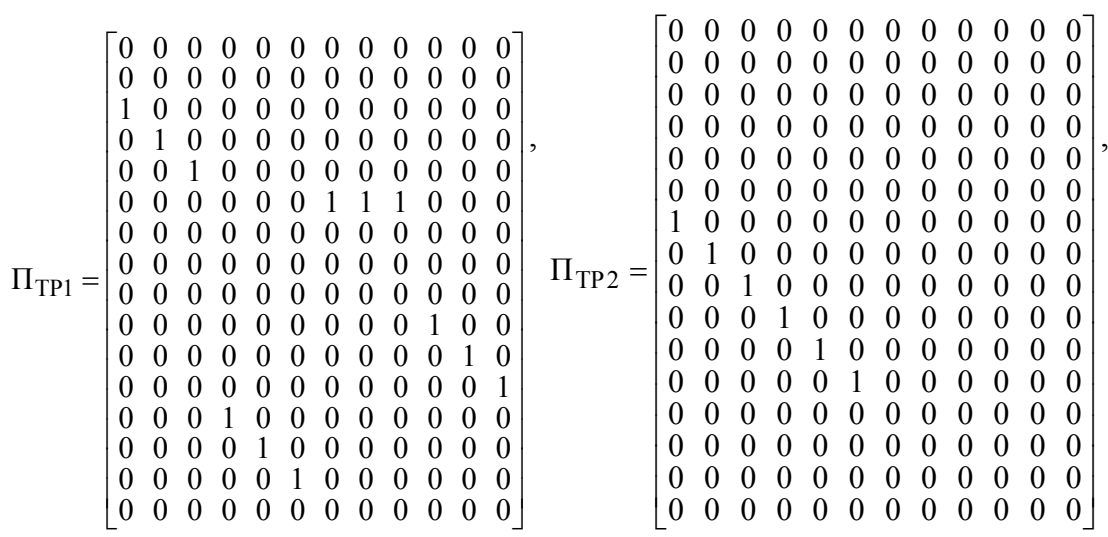

$$
\Pi_{\mathrm{am}}=\left[\begin{array}{llllllllllll}
0 & 0 & 0 & 0 & 0 & 0 & 0 & 0 & 0 & 0 & 0 & 0 \\
0 & 0 & 0 & 0 & 0 & 0 & 0 & 0 & 0 & 0 & 0 & 0 \\
0 & 0 & 0 & 0 & 0 & 0 & 0 & 0 & 0 & 0 & 0 & 0 \\
0 & 0 & 0 & 0 & 0 & 0 & 0 & 0 & 0 & 0 & 0 & 0 \\
0 & 0 & 0 & 0 & 0 & 0 & 0 & 0 & 0 & 0 & 0 & 0 \\
0 & 0 & 0 & 0 & 0 & 0 & 0 & 0 & 0 & 0 & 0 & 0 \\
0 & 0 & 0 & 0 & 0 & 0 & 0 & 0 & 0 & 0 & 0 & 0 \\
0 & 0 & 0 & 0 & 0 & 0 & 0 & 0 & 0 & 0 & 0 & 0 \\
0 & 0 & 0 & 0 & 0 & 0 & 0 & 0 & 0 & 0 & 0 & 0 \\
0 & 0 & 0 & 0 & 0 & 0 & 0 & 0 & 0 & 0 & 0 & 0 \\
0 & 0 & 0 & 0 & 0 & 0 & 0 & 0 & 0 & 0 & 0 & 0 \\
0 & 0 & 0 & 0 & 0 & 0 & 0 & 0 & 0 & 0 & 0 & 0 \\
1 & 0 & 0 & 0 & 0 & 0 & 0 & 0 & 0 & 0 & 0 & 0 \\
0 & 1 & 0 & 0 & 0 & 0 & 0 & 0 & 0 & 0 & 0 & 0 \\
0 & 0 & 1 & 0 & 0 & 0 & 0 & 0 & 0 & 0 & 0 & 0 \\
0 & 0 & 0 & 0 & 0 & 0 & 1 & 1 & 1 & 0 & 0 & 0
\end{array}\right]
$$
гляд:

Вектор інтегрування для даної системи матиме ви-

$$
\mathrm{p} \overrightarrow{\mathrm{Y}}=\left(\mathrm{pi}_{1}, \mathrm{pi}_{2}, \ldots, \mathrm{pi}_{43}, \mathrm{p} \gamma, \mathrm{p} \omega, 1\right),
$$

де $i_{1}, \ldots, i_{43}$ - струми віток силової схеми (рис. 3$), \gamma-$ кут повороту ротора АД, $\omega$ - кутова швидкість обертання АД, p - оператор диференціювання, останній елемент вектора інтегрування - похідна часу за часом, рівна 1.

Вектор інтегрування розраховується. Щоб його визначити необіхідно знати параметри (активні опори та індуктивності) вентилів, які залежать від стану вентиля. Стан вентиля визначається шляхом розв'язку математичної моделі системи керування вентильним перетворювачем (АIH). До складу цієї математичної моделі входять логічні рівняння, які визначають умови відкривання і закривання вентилів.

Умова відкривання вентилів AIH1 (катодної і анодної вентильних груп КВГ1, АВГ1, рис. 3) має вигляд:

$(\mathrm{TM} 1(\mathrm{i})>0) \cap(\mathrm{TM} 1(\mathrm{i})<\pi) \cap(\mathrm{VT}(\mathrm{i})>0) \cap(\mathrm{IT}(\mathrm{i})=0)=$ true. $(i=1 \ldots 6)$

В цьому виразі: ТМ(i) - масив розмірністю 6, елементи якого рівні

$\operatorname{TM} 1(1)=\gamma_{\text {інв }} ; \operatorname{TM} 1(2)=\operatorname{TM} 1(1)+4 \pi / 3 ; \operatorname{TM} 1(3)=$ $\operatorname{TM} 1(1)+2 \pi / 3$

$\operatorname{TM} 1(4)=\mathrm{TM} 1(1)+\pi ; \quad \operatorname{TM} 1(5)=\mathrm{TM} 1(2)+\pi ;$ $\operatorname{TM} 1(6)=\operatorname{TM} 1(3)+\pi$, де VT(i) $(\mathrm{i}=1 \ldots$ 6) - елементи масиву напруг на вентилях, які відповідають напругам на вентилях катодної і анодної вентильних груп 1; IT(i) $(\mathrm{i}=1 \ldots 6)-$ елементи масиву функцій стану вентилів, які відповідають вентилям цих вентильних груп,

$$
\gamma_{\text {інв }}=\int_{0}^{\mathrm{t}} 2 \pi \mathrm{f}_{\text {вих }} \mathrm{dt},
$$

$\mathrm{f}_{\text {вих }}$ - частота вихідної напруги АIH $1 ; \mathrm{t}$ - розрахунковий час.

Умова відкривання вентилів діодного моста на виході АІН1 (катодної КВГ2 і анодної АВГ2 вентильних груп) матиме вигляд:

$$
(\mathrm{VT}(\mathrm{i})>0) \cap(\mathrm{IT}(\mathrm{i})=0)=\text { true, }
$$

де VT(i) (i = 7 .. 12) - елементи масиву напруг на вентилях, які відповідають напругам на вентилях катодної і анодної вентильних груп 2; IT(i) (i = 7 ... 12) - елементи масиву функцій стану вентилів, які відповідають вентилям цих вентильних груп.

Умова відкривання вентилів АIH2 (катодної і анодної вентильних груп КВГЗ, АВГЗ, рис. 3) має вигляд:

$(\mathrm{TM} 2(\mathrm{j})>0) \cap(\mathrm{TM} 2(\mathrm{j})<\pi) \cap(\mathrm{VT}(\mathrm{i})>0) \cap(\mathrm{IT}(\mathrm{i})=0)$ = true. $(\mathrm{i}=13 \ldots 18)$

В цьому виразі: ТМ2 - масив розмірністю 6, елементи якого рівні

$\operatorname{TM} 2(1)=\operatorname{TM} 1(1)-\pi / 6 ; \operatorname{TM} 2(2)=\operatorname{TM} 2(1)+4 \pi / 3 ;$ $\mathrm{TM} 2(3)=\mathrm{TM} 2(1)+2 \pi / 3$; 
$\mathrm{TM} 2(4)=\mathrm{TM} 2(1)+\pi ; \quad \operatorname{TM} 2(5)=\mathrm{TM} 2(2)+\pi ;$ $\mathrm{TM} 2(6)=\mathrm{TM} 2(3)+\pi ; \mathrm{j}=\mathrm{i}-12$,

де VT(i) (i = $13 \ldots 18)$ - елементи масиву напруг на вентилях, які відповідають напругам на вентилях катодної і анодної вентильних груп 3; IT(i) (i = 13 ... 18) - елементи масиву функцій стану вентилів, які відповідають вентилям цих вентильних груп.

Умова відкривання вентилів діодного моста на виході АІН2 (катодної КВГ4 і анодної АВГ4 вентильних груп) матиме вигляд:

$$
(\mathrm{VT}(\mathrm{i})>0) \cap(\mathrm{IT}(\mathrm{i})=0)=\text { true },(\mathrm{i}=19 \ldots 24)
$$

де VT(i) (i = 19 .. 24) - елементи масиву напруг на вентилях, які відповідають напругам на вентилях катодної і анодної вентильних груп 4; IT(i) (i = 19 ... 24) - елементи масиву функцій стану вентилів, які відповідають вентилям цих вентильних груп.

Умова закривання вентилів інвертора АIH1 має вигляд: $(\mathrm{TM1}(\mathrm{i})>\pi) \cap(\mathrm{IT}(\mathrm{i})=0)=$ true, $(\mathrm{i}=1 \ldots 6)$, а для закривання вентилів інвертора АIH2 має вигляд: $(\mathrm{TM} 2(\mathrm{j})>\pi) \cap(\mathrm{IT}(\mathrm{i})=0)=$ true, $(\mathrm{i}=13 \ldots 18, \mathrm{j}=\mathrm{i}-12)$.

Закривання вентилів інвертора під час протікання через нього струму здійснюється за наступним алгоритмом.

1. Відповідному діоду вихідного діодного моста присвоюється значеня струму, який протікає через вентиль, що закривається; параметри даного діода змінюються на значення для відкритого стану (діод відкривається) (для прикладу, якщо закривається вентиль i-тий, то необхідно відкрити діод i+6).

2. Струму вентиля, який закривається присвоюється нуль; параметрам даного вентиля присвоюються значення для закритого стану (вентиль закривається).

3. Значення струму через джерело живлення збільшується на величину струму вентиля, який закривається.

Такий алгоритм відображає процеси під час примусового закривання вентилів інвертора. Закривання діодів відбувається в момент часу, коли їх струми переходять через нуль 3 додатного у від'ємне значення.

Програмно математична модель електроприводу водяного насоса ВПВ реалізована 3 використанням програмного середовища, реалізованого мовою FORTRAN. Загальні підпрограми є типовими і призначені для: виконання математичних операцій над матрицями; чисельного інтегрування систем диференційних рівнянь методом Рунге-Кутта 2-го порядку; розв'язування систем алгебраїчних рівнянь методом Гауса; визначення моментів природного закривання вентилів.

Результати моделювання у вигляді часових залежностей наведені на рис. 4, 5. Вони підтверджують теоретичні твердження про можливість використання АБ $з$ АІН у схемах автономного джерела для електроживлення АД приводу водяного насоса ВПВ.

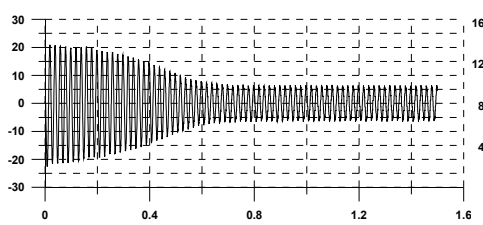

a)

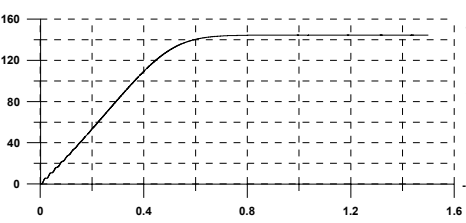

б)

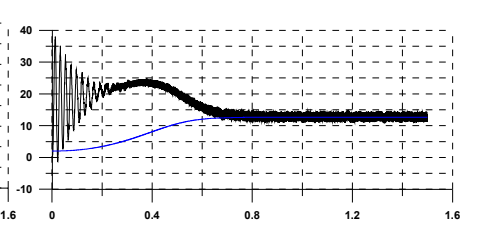

6)

Рис.4. Результати моделювання при прямому пуску АД від мережі: a) струм статора АД; б) кутова швидкість обертання ротора АД; в) електромагнітний момент і момент навантаження АД.

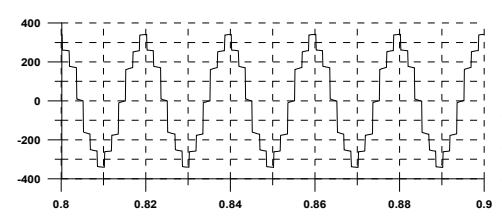

a)

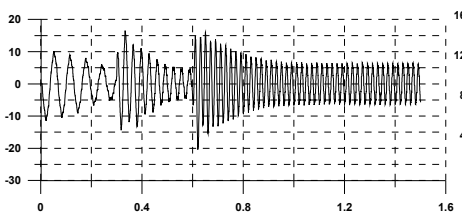

б)

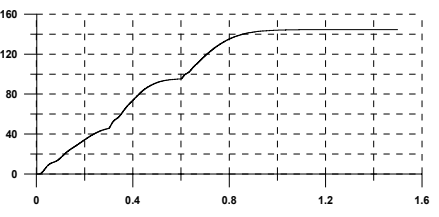

в)

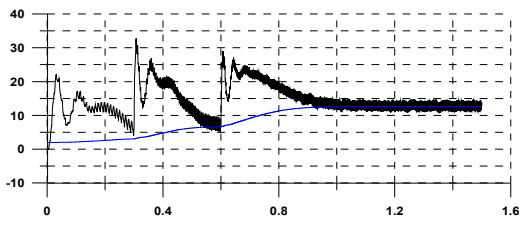

2)

Рис. 5. Результати моделювання при частотному пуску від автономного джерела 3 АБ:

$a$ )квазісинусоїдальна форма кривої напруги живлення АД; б) струм статора при пуску АД; в) кутова швидкість обертання ротора АД; г) електромагнітний момент і момент навантаження АД. 
Для перевірки адекватності математичної моделі була створена експериментальна установка (Bodnar and Shapovalov, 2010), на якій проведені дослідження параметрів автономного джерела з АБ для резервування електроживлення системи ВПВ.

Результати експериментальних досліджень наведені на рис.6, рис.7. На рис. 6показані криві струму і напруги живлення АД від мережі і автономного джерела з АБ при пуску і роботі насоса, форма кривої напруги живлення АД. На рис. 7 вказано залежності, зняті експериментально, вихідної напруги джерела (рис.7.a) і тиску насоса (рис. 7.б) впродовж тривалої роботи електроприводу насоса (1 год.).

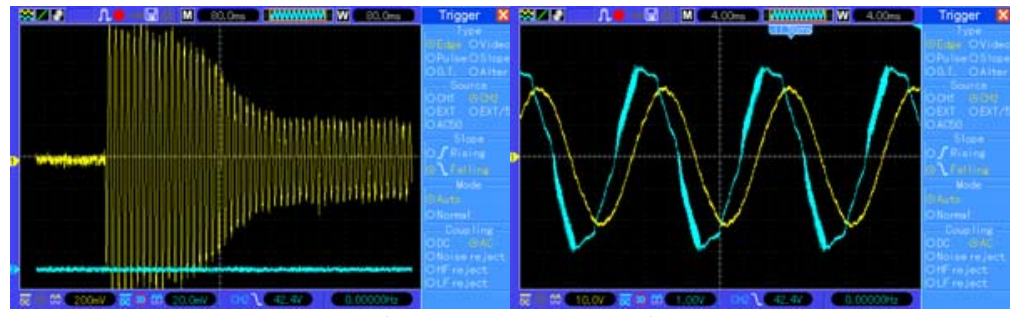

a)

б)

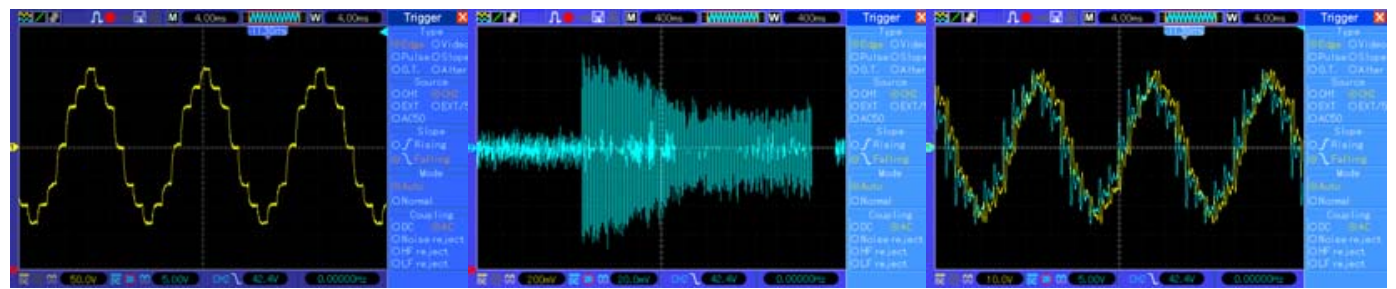

в)

2)

d)

Рис. 6. Результати експериментів: a) струм статора при прямому пуску АД; б) форма напруги і струму при прямому пуску АД; в)квазісинусоїдальна форма кривої напруги живлення АД при пуску; г) струм статора при пуску від АБ; $\partial$ ) форма кривої напруги і струму при пуску АД від АБ з АІН.

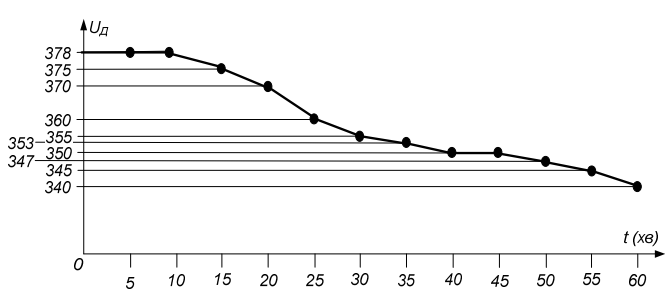

a)

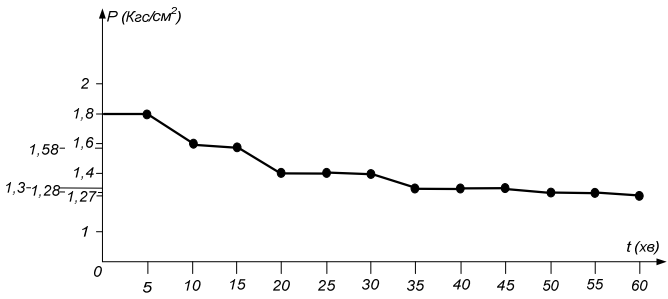

б)

Рис. 7. Результати експериментів: a) напруга живлення АД насоса; б) тиск в системі ВПВ.

\section{Висновки}

Порівнюючи результати досліджень в розглянутих випадках, можна стверджувати, що максимальна розбіжність між результатами математичного моделювання і експериментальними дослідженнями (форма і характер зміни струму та напруги) складає до 5\%, що підтверджує високий рівень адекватності математичної моделі, яка може бути використана для проектування автономних джерел 3 АБ для живлення АД приводу насоса ВПВ будь-якої потужності.

Проведені дослідження процесів підтвердили теоретичні положення про можливість використання в автономному резервному джерел і для живлення АД системи ВПВ акумуляторних батарей, які забезпечать роботу насоса в надзвичайних ситуаціях на протязі тривалого часу (1 год.) до прибуття оперативнорятувальних підрозділів. Запропонована розробка може мати універсальне застосування, наприклад для забезпечення автономного водопостачання для підтримки неперервних технологічних процесів у надзвичайних ситуаціях.

\section{Бібліографічні посилання}

Shesterenko, V.Je. (2004). Systemy elektrospozhyvannja ta elektropostachannja promyslovyh pidpryjemstv. NUHT.-Nova knyga (in Ukrainian).

Seki, Y., Takahashi, Y., Koda, T. (1995). Power Pack IGBT: High Power $(2,5 \mathrm{kV}, 1 \mathrm{kA}) \mathrm{RC}-\mathrm{IGBT}$ with Highly Reliable Flat Package. EPE'95.Proceeding of 6th European Conference on Power Electronics and Applications. Sevilla, Spain. 1, 1051-1055.

Brunner, H., Hierholzer, M., Spanke, R. (1995). 3300 V IGBT-Modulle for traction application. EPE'95. Proceeding of 6th European Conference on Power Electronics and Applications. Sevilla, Spain. 1, 10561059. 
Bodnar, G.J., Shapovalov, O.V (2014). Pat. 105287 Ukrai'na, MPK (2014.01) A62C 37/00, A62C 37/46 (2006.01), F04D 25/06 (2006.01), H02P 25/00. Elektropryvid nasosa pidvyshuvacha tysku vody. a201211659; zajavl. 09.10.2012; opubl. 25.04.2014, Bjul. № 8 .

Plahtyna, O.G. Bodnar, G.J., Kucyk, S.S. (1998). Doslidzhennja systemy «kaskadnyj invertor naprugy asynhronnij dvygun». Visnyk HDTU. Harkiv: Vyd-vo HDTU.

Bodnar, G.J., Shapovalov, O.V. (2012). Rozrobka avtonomnogo dzherela zhyvlennja dlja protypozhezhnyh system vnutrishn'ogo vodopostachannja. Zbirnyk naukovyh prac' «Pozhezhna bezpeka» L.: LDU BZhD, 20, 180-186.

Bodnar, G.J., Shapovalov, O.V. (2008). Elektropryvid vodjanogo nasosa protypozhezhnogo vodoprovodu $\mathrm{Z}$ avtonomnymzhyvlennjam. Visnyk NTU «HPI». Teoryja y praktyka.- H.: NTU «HPI», 355-356.

Plahtyna, E.G. (1986). Matematicheskoe modelirovanie jelektromashino-ventil'nyh sistem. L'vov: Izd-vo «Vishha shkola». (in Russian).

Bodnar, G.J., Shapovalov, O.V. (2010). Matematychne modeljuvannja puskovyh rezhymiv elektropryvodu nasosa pidvyshhuvacha tysku vody systemy protypozhezhnogo vodopostachannja. Visnyk NTU «HPI». Teoryja y praktyka, 373-374.

Стаття надійшла до редакиії 15.09.2016 